\title{
Protective Effect of Lonicerae Flos Aqueous Extracts on a Pressure Overload-induced Heart Failure Model
}

\author{
Jae-wook Shin, Woo-seok Jang, Kyung-min Baek \\ Dept. of Cardiovascular and Neurologic Diseases of Korean Internal Medicine, \\ Daegu Oriental Hospital of Daegu Haany University
}

\section{Protective Effect of Lonicerae Flos Aqueous Extracts on a Pressure Overload-induced Heart Failure Model}

\author{
Jae-wook Shin, Woo-seok Jang, Kyung-min Baek \\ Dept. of Cardiovascular and Neurologic Diseases of Korean Internal Medicine, \\ Daegu Oriental Hospital of Daegu Haany University
}

\begin{abstract}
Objectives: Lonicerae flos (LF), a dried flower part of Lonicera japonica Thunb., has been widely used in Korean medicine as anti-inflammatory and antioxidative agent. The purpose of this study was to determine the cardioprotective effects of LF, through potential antioxidant effects, on the pressure overload (PO)-induced heart failure (HF) in C57BL/6 mice after transverse aortic constriction (TAC) surgery.

Methods: Resveratrol ( $10 \mathrm{mg} / \mathrm{kg}$ body weight) or LF (125, 250 or $500 \mathrm{mg} / \mathrm{kg}$ body weight) was orally administered, once daily for 14 days, starting 14 days after TAC surgery. Changes in the mortality, body weights, heart weights, histopathology of the heart, and antioxidant defense systems of the heart were analyzed.

Results: Marked and noticeable increases of heart weights, mortalities, and hypertrophic, focal, and lytic fibrotic histological changes in the LVs were observed, with destruction of heart antioxidant defense systems after surgery. However, HF signs, induced by TAC surgery through PO, and destruction of heart antioxidant defense systems were significantly and dose-dependently inhibited by 14 days of maintained oral treatment with LF 500,250 or $125 \mathrm{mg} / \mathrm{kg}$. Treatment with $250 \mathrm{mg} / \mathrm{kg} \mathrm{LF}$ was comparable to treatment with $10 \mathrm{mg} / \mathrm{kg}$ resveratrol.

Conclusions: The results in this study suggest that oral administration of LF favorably relieves PO-induced HF following TAC, through increase of heart antioxidant defense systems. The overall effects of $250 \mathrm{mg} / \mathrm{kg} \mathrm{LF}$ were similar to those of 10 $\mathrm{mg} / \mathrm{kg}$ resveratrol. More detailed mechanistic studies should be conducted in the future, with screening of the biologically active compounds in LF.
\end{abstract}

$\overline{\text { Key words: }}$ heart failure, Lonicerae flos, pressure overload, cardioprotective

· 투고일: 2017.09.11, 심사일: 2017.11.27, 게재확정일: 2017.12.17

- Corresponding author: Kyung-min Baek Dept of Cardiovascular and Neurologic Diseases of Korean Internal Medicine $2^{\text {nd }}$ floor, Daegu Oriental Hospital, 136 Sinchendong-ro, Suseong-gu, Daegu, Republic of Korea

TEL: +82-53-770-2118 FAX: +82-53-770-2055 E-mail: kmb1004@hanmail.net

. 이 논문은 2016년도 대구한의대학교 대학원 한의학 석사학위 논문임.

\section{Introduction}

Heart failure (HF) is a global problem with an estimated prevalence of 38 million patients worldwide, a number that is increasing with the aging of the population ${ }^{1}$. HF is an important healthcare issue 
because of its high prevalence, mortality, morbidity, and cost of care ${ }^{2}$. HF can be caused by disease such as ischemic heart disease, hypertension, valve or myocardium structural defects and arrhythmias. The classic clinical syndrome of HF is characterized by fluid retention leading to pulmonary congestion and peripheral edema and by low cardiac output, that combined may cause a severe limitation of exercise capacity ${ }^{4}$. Conventional treatment of $\mathrm{HF}$ involves oxygen therapy, diet, angiotensin-convertising enzyme inhibitors (ACEI), diuretics, anti platelets or beta-blockers, etc $c^{5}$. Despite existing therapies for HF, the current 1-year mortality rate after diagnosis of symptomatic $\mathrm{HF}$ remains at $25 \%$ to $40 \%$. Accordingly, there are a few efforts in domestic and foreign to find other treatment for HF. However, there are little research on the mechanisms how these treatment can control heart damage and on optimal stage to use.

Lonicerae Flos (Lonicerae japonica Thunb, LF), also called Jinyinhua (金銀花) is a widely used herb prescribed in many Korean herbal formulas against gastroesophageal reflux disease, lung disease, carcinoma, etc. Pharmacological studies show that LF possessed various actions, such as anti-inflammatory, antiviral, antidiabetic, antiallergic, and antioxidants ${ }^{7-9}$. Because LF has beneficial effect on oxidative damages and cytoprotective action, we hypothesized that LF could also have positive effects in PO induced HF by antioxidant mechanism. And therefore there are no studies about effects of LF on heart.

So this study performed for the cardioprotective effects of LF on the PO-induced HF by TAC in mice, with antioxidant effects. The changes on the mortality, body weight, heart weights, indicators of antioxidant defense system and histopathology of heart were investigated.

\section{Materials and methods}

\section{Animals and husbandry}

One hundred 6-week old male SPF/VAF inbred C57BL/6NCrljOri [C57BL/6] mice (OrientBio, Seungnam, Korea) were used after acclimatization for 7 days. In this study, forty transverse aortic constriction (TAC) and eight sham operated mice were sorted out based on the weights at two weeks after TAC surgery (mean weights: $21.60 \pm 0.74 \mathrm{~g}$ ), and divided into six groups (Table 1).

\section{Preparations and administration of test materials}

Three different dosages, 50, 25 and $12.5 \mathrm{mg}$ of LF were directly dissolved in distilled water $1 \mathrm{ml}$, and administered in a volume of $10 \mathrm{ml} / \mathrm{kg}$ as equivalence to 500,250 and $125 \mathrm{mg} / \mathrm{kg}$ using gastric gavages by oral, once a day for 14 days from 14 days after TAC operation, and resveratrol also dissolved in distilled water and orally administered at a dose level of $10 \mathrm{mg} / \mathrm{kg}$, in a volume of $10 \mathrm{ml} / \mathrm{kg}$. In sham and TAC control mice, instead of test materials, same volumes of distilled water as vehicle were administered once a day for 14 days from 14 days by oral after TAC surgery, respectively (Table 1).

Table 1. Experimental Design Used in the Present Study

\begin{tabular}{|c|c|c|c|}
\hline Groups & Operation & $\begin{array}{l}\text { Group } \\
\text { identification }\end{array}$ & Treatment \\
\hline Control & Sham & Sham control & $\begin{array}{l}\text { Distilled water } \\
10 \mathrm{~mL} / \mathrm{kg} / \text { day }\end{array}$ \\
\hline Control & $\mathrm{TAC}$ & TAC control & $\begin{array}{l}\text { Distilled water } \\
10 \mathrm{~mL} / \mathrm{kg} / \text { day }\end{array}$ \\
\hline Reference & $\mathrm{TAC}$ & Resveratrol & $\begin{array}{l}\text { Resveratrol } \\
10 \mathrm{mg} / \mathrm{kg} / \text { day }\end{array}$ \\
\hline Active & $\mathrm{TAC}$ & LF 500 & LF 500 mg/kg/day \\
\hline Active & $\mathrm{TAC}$ & LF 250 & LF $250 \mathrm{mg} / \mathrm{kg} /$ day \\
\hline Active & $\mathrm{TAC}$ & LF 125 & LF 125 mg $/ \mathrm{kg} /$ day \\
\hline
\end{tabular}




\section{TAC operation}

The mice were intubated with tubing by oral and ventilated at $0.2 \mathrm{~mL}$ tidal air volume. A $3 \mathrm{~mm}$ center thoracotomy was treated. The transverse aortic arch was tied (7-0 Prolene) between the innominate artery and left common carotid artery using an overlying 28-gauge needle. After that, the needle was eliminated, leaving a detached region of stenosis. The chest was closed. The pneumothorax was clearly evacuated. Some mice underwent a sham operation in which the aortic arch was visualized but not ligated.

\section{Mortalities}

Based on the Functional Observational Battery (FOB), all abnormal mortalities were represented before and after administration twice a day during the first day of administration to the last day of drug treatment.

\section{Body weight measurements}

Changes in weight of body were evaluated at one day before initial resveratrol or LF administration, the day of first administration, 1, 7, 13 and 14 days after initial test material administration with an automatic electronic balance (Precisa Instrument, Dietikon, Switzland).

\section{Heart weight measurements}

At sacrifice, the heart weights in all survived animals were evaluated at gram levels, separately with an automatic electronic balance (Precisa Instrument, Dietikon, Switzland).

To reduce individual differences, the relative weights (percentage of body weights) were calculated using weight of body at sacrifice and absolute weight of heart as following equation : (absolute weights of heart/weight of body at sacrifice $) \times 100$. 7. Analysis of Antioxidant defence system
The total protein amount for the determination of enzyme antioxidant, GSH, and lipid peroxidation assays was refered to the Lowry protein assay.

\section{1) Analysis of lipid peroxidation}

Quantifying levels of lipid peroxidation, thiobarbituric acid reactive substances (TBARS) made due to acid-heating reactions were evaluated. TBARS absorbance was analyzed spectrophotometrically at $535 \mathrm{~nm}$ of optical density (OD) with a UV/VIS spectrophotometer (OPTIZEN POP, Mecasys, Daejeon, Korea) and findings are demonstrated as MDA equivalents ( $\mathrm{nM} / \mathrm{g}$ of protein).

2) Analysis of CAT and SOD activity

The CAT activity level was evaluated by the corrosion of the hydrogen peroxide at OD $240 \mathrm{~nm}$ using a UV/VIS spectrophotometer (OPTIZEN POP, Mecasys, Daejeon, Korea). Results were observed as $\mathrm{U} / \mathrm{g}$ protein. SOD activity was measured at $560 \mathrm{~nm}$ of $\mathrm{OD}$ by the degree of inhibition of this reaction, and was observed as $\mathrm{U} / \mathrm{g}$ protein.

3) Analysis of GSH levels

Reduced and disulphide forms of GSH levels in tissue homogenate samples were estimated with the method depicted by Tietze. Reduced GSH is recycled with glutathione reductase and nicotinamide adenine dinucleotide phosphate (NADPH), which is related to the absorption change at $412 \mathrm{~nm}$, related with the reduction of diothio-bis-(2-nitrobenzoic acid) (DTNB). This analysis was modified for the use in a microplate reader (Tecan, Männedorf, Switzerland).

\section{Histological process}

Approximately corresponding regions of individual hearts, taken from survived mice at sacrifice (five in each group), were obliquely cut based upon the ventricles as one part of each heart. To investigate more specific changes, total thicknesses of endocardium 
to pericardium ( $\mu \mathrm{m} /$ heart) in left ventricle ( $\mathrm{LV})$, mean numbers of lytic necrotic muscle fibers of heart (myofibers/1000 myofibers) and diameters of muscle fibers of heart ( $\mu \mathrm{m} /$ fiber) were evaluated using a computer-assisted progrom (iSolution FL ver 9.1, IMT i-solution INC., Quebec, Canade) for image anlysis under $\mathrm{H} \& \mathrm{E}$ stain with the mean percentages of perivascular and interstitial collagen fiber occupied parts in $\mathrm{LV}\left(\% / \mathrm{mm}^{2}\right.$ of field) under Sirius red (SR) stain.

\section{Statistical analyses}

All Data were displayed as mean \pm standard deviations (SD). Multiple comparison tests for the different dose groups were prosecuted. Variance homogeneity was examined using the Levene test. If the Levene test exhibited no significant deviations from variance homogeneity, the obtained data were analyzed by one way ANOVA test and least-significant differences (LSD) multi-comparison test to determine which pairs of group comparison were clearly different. When great deviations from variance homogeneity were detected at Levene test, Kruskal-Wallis $\mathrm{H}$ test, a non-parametric comparison test, was done. If an important difference was detected in the Kruskal-Wallis
H test, the Mann-Whitney U (MW) test was conducted to determine the specific pairs of group comparison that are considerably different. Statistical analyses were conducted using SPSS for Windows (Release 14.0K, IBM SPSS Inc., Armonk, NY, USA).

\section{Results}

\section{Survivability}

Unscheduled mortalities were not demonstrated in sham-operated control mice throughout the whole experimental periods, but three mice (3/8; $37.5 \%$ ) in TAC control died within 14 days of experimental periods; each of one mouse died at 3,8 and 10 days after initial administration, respectively. In addition, one mouse $(1 / 8 ; 12.5 \%)$ administered with resveratrol $10 \mathrm{mg} / \mathrm{kg}$ were died at 6 days after initial administration, and also one mouse (1/8; 12.5\%) at 7 days after initial administration in LF $250 \mathrm{mg} / \mathrm{kg}$ treated mice. Two mice (2/8; 25.0\%) among LF 125 $\mathrm{mg} / \mathrm{kg}$ treated mice died; each of one at 10 and 11 days after initial administration. However, no unscheduled mortalities were demonstrated in LF $500 \mathrm{mg} / \mathrm{kg}$ treated mice throughout the whole 14 days of experimental periods in this experiment (Table 2).

Table 2. Mortalities in Sham or TAC Operated Mice

\begin{tabular}{|c|c|c|c|c|c|c|c|c|c|c|c|c|c|c|c|c|}
\hline \multirow[b]{2}{*}{ Groups } & \multicolumn{14}{|c|}{ Days of administration } & \multirow{2}{*}{ Total* } & \multirow{2}{*}{ Survival (\%) } \\
\hline & 0 & 1 & 2 & 3 & 4 & 5 & 6 & 7 & 8 & 9 & 10 & 11 & 12 & 13 & & \\
\hline \multicolumn{17}{|l|}{ Controls } \\
\hline Sham & 0 & 0 & 0 & 0 & 0 & 0 & 0 & 0 & 0 & 0 & 0 & 0 & 0 & 0 & $0 / 8$ & 100.00 \\
\hline $\mathrm{TAC}$ & 0 & 0 & 0 & 1 & 0 & 0 & 0 & 0 & 1 & 0 & 1 & 0 & 0 & 0 & $3 / 8$ & 62.50 \\
\hline Resveratrol $10 \mathrm{mg} / \mathrm{kg}$ & 0 & 0 & 0 & 0 & 0 & 0 & 1 & 0 & 0 & 0 & 0 & 0 & 0 & 0 & $1 / 8$ & 87.50 \\
\hline \multicolumn{17}{|l|}{ LF treated } \\
\hline $500 \mathrm{mg} / \mathrm{kg}$ & 0 & 0 & 0 & 0 & 0 & 0 & 0 & 0 & 0 & 0 & 0 & 0 & 0 & 0 & $0 / 8$ & 100.00 \\
\hline $250 \mathrm{mg} / \mathrm{kg}$ & 0 & 0 & 0 & 0 & 0 & 0 & 0 & 1 & 0 & 0 & 0 & 0 & 0 & 0 & $1 / 8$ & 87.50 \\
\hline $125 \mathrm{mg} / \mathrm{kg}$ & 0 & 0 & 0 & 0 & 0 & 0 & 0 & 0 & 0 & 0 & 1 & 1 & 0 & 0 & $2 / 8$ & 75.00 \\
\hline
\end{tabular}

Values are expressed as number of expired animals.

* Total mortalities for 14 days of observation periods-expired animals/total animals (eight mice in each group)

$\mathrm{TAC}$ : transverse aortic constriction, LF : Lonicerae flos aqueous extracts 
2. Changes on the body weight

Significant changes on the weight of body for 14 days of experimental periods were not detected in all TAC operated mice as compared to sham control mice, and also marked changes on the body weight and gains were not detected in all three different dosages of LF or resveratrol $10 \mathrm{mg} / \mathrm{kg}$ administrated mice as compared to TAC control mice, respectively (Table 3).

Table 3. Body Weight Gains Observed in Sham or TAC Operated Mice

\begin{tabular}{|c|c|c|c|}
\hline \multirow{2}{*}{$\begin{array}{ll}\text { Groups } & \text { Times } \\
\end{array}$} & \multicolumn{2}{|c|}{ Body weights at } & \multirow{2}{*}{ Weight gains $[\mathrm{B}-\mathrm{A}]$} \\
\hline & First administration [A] & Sacrifice [B] & \\
\hline \multicolumn{4}{|l|}{ Controls } \\
\hline Sham & $19.59 \pm 0.75$ & $20.73 \pm 0.96$ & $1.14 \pm 0.48$ \\
\hline TAC & $19.56 \pm 0.67$ & $20.62 \pm 1.00$ & $1.18 \pm 0.66$ \\
\hline Resveratrol $10 \mathrm{mg} / \mathrm{kg}$ & $19.45 \pm 0.75$ & $20.56 \pm 1.01$ & $1.24 \pm 0.45$ \\
\hline \multicolumn{4}{|l|}{ LF treated } \\
\hline $500 \mathrm{mg} / \mathrm{kg}$ & $19.70 \pm 0.73$ & $20.83 \pm 1.12$ & $1.13 \pm 0.66$ \\
\hline $250 \mathrm{mg} / \mathrm{kg}$ & $19.68 \pm 1.05$ & $20.73 \pm 1.22$ & $1.16 \pm 1.00$ \\
\hline $125 \mathrm{mg} / \mathrm{kg}$ & $19.58 \pm 0.52$ & $20.77 \pm 1.11$ & $1.22 \pm 0.81$ \\
\hline
\end{tabular}

Values are expressed as Mean \pm S.D. of variable numbers of the animals according to mortality (see Table 2), g.

$\mathrm{TAC}$ : transverse aortic constriction, LF : Lonicerae flos aqueous extracts

\section{Changes on the heart weight}

Noticeable hypertrophic changes were demonstrated in TAC control mice as compared to sham control mice; as a result, significant $(\mathrm{p}\langle 0.01)$ increases of relative and absolute weights of heart were demonstrated in TAC control mice at 14 days after the end of administration (28 days after TAC surgery). However, these heart hypertrophic changes induced by TAC were remarkably inhibited by treatment of LF 500 , 250 and $125 \mathrm{mg} / \mathrm{kg}$, and by resveratrol $10 \mathrm{mg} / \mathrm{kg}$, dose dependantly, as compared with TAC control; significant $(\mathrm{p}<0.01)$ and dose-dependent decreases of absolute and relative weights of heart were noticed in all three different dosages of LF administered mice, and in resveratrol $10 \mathrm{mg} / \mathrm{kg}$ treated mice (Fig. 1, 2).

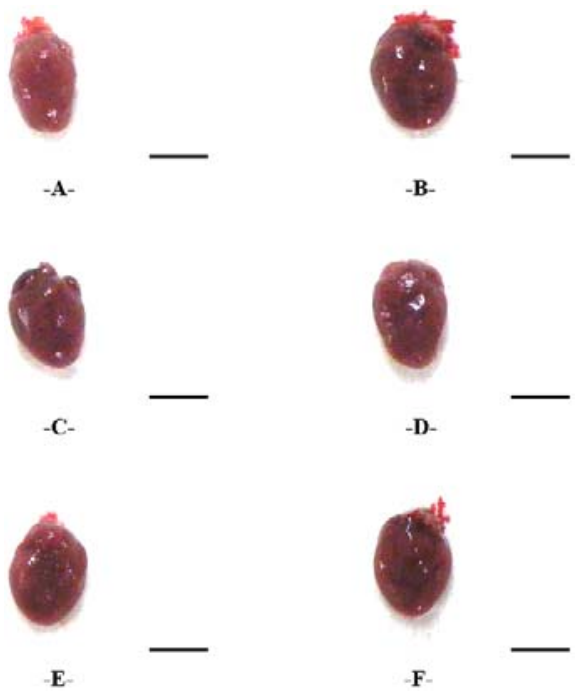

Fig. 1. The representative gross images of heart, selected from sham or TAC operated mice.

A : sham control, B : TAC control, C : resveratrol $10 \mathrm{mg} / \mathrm{kg}$, D : LF $500 \mathrm{mg} / \mathrm{kg}$, E : LF $250 \mathrm{mg} / \mathrm{kg}$, F : LF $125 \mathrm{mg} / \mathrm{kg}$

LF : Lonicerae flos aqueous extracts, TAC : transverse aortic constriction

Scale bars : $5 \mathrm{~mm}$ 


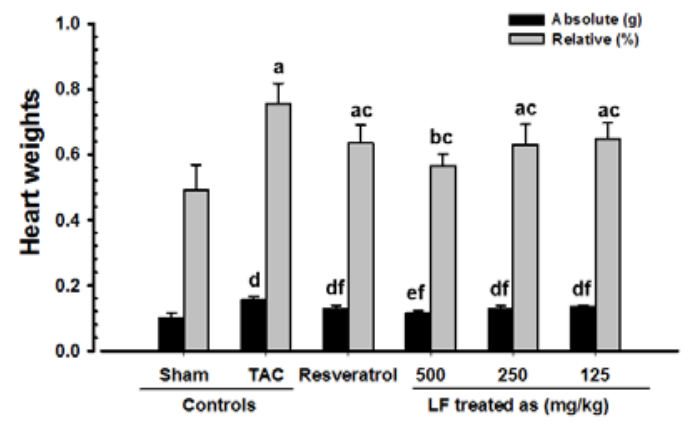

Fig. 2. Changes on the heart weights in sham or TAC operated mice.

Values are expressed as Mean \pm S.D. of variable numbers of mice according to mortality (see Table 2), g.

TAC : transverse aortic constriction

LF : Lonicerae flos aqueous extracts

${ }^{a} p<0.01$ and ${ }^{b} p<0.05$ as compared to sham control by LSD test

${ }^{c} p<0.01$ as compared to TAC control by LSD test ${ }^{d} p<0.01$ and ${ }^{e} p<0.05$ as compared to sham control by $\mathrm{MW}$ test

${ }^{\mathrm{f}} p<0.01$ as compared to TAC control by MW test

4. Effects on the heart antioxidant defense system

1) Changes on the heart MDA levels

Significant $(p<0.01)$ increases of cardiac lipid peroxidation, elevation of the MDA levels, were observed in TAC control mice, as compared with sham control mice. However, these increase of MDA levels were remarkably $(p<0.01)$ decreased by treatment of LF, dose-dependently. In addition, the heart lipid peroxidation in resveratrol $10 \mathrm{mg} / \mathrm{kg}$ treated mice were also significantly $(p<0.01)$ decreased as compared with TAC control mice (Table 4).

2) Changes on the heart GSH contents
Significant $(p<0.01)$ decrease of heart endogenous antioxidant, the GSH content, were detected in TAC control mice as compared with sham control mice. However, these decreases of cardiac GSH contents induced by TAC operation were significantly $(p<0.01$ or $p<0.05)$ and dose-dependently inhibited by treatment of 14 days continuous oral treatment of LF 500 , 250 and $125 \mathrm{mg} / \mathrm{kg}$, respectively. In addition, the heart GSH contents in resverastrol $10 \mathrm{mg} / \mathrm{kg}$ treated mice were also significantly $(p<0.01)$ and remarkably increased as compared with TAC control mice (Table 4).

3) Changes on the heart CAT activity

Significant $(p<0.01)$ decreases of heart endogenous antioxidative enzyme, the CAT activity were detected in TAC control mice as compared with sham control mice. However, these decreases of cardiac CAT activities were markedly ( $p<0.01$ or $p<0.05)$ and dose-dependently inhibited by treatment of 14 days continues oral treatment of LF at any dose examined. In addition, the heart CAT activities in resveratrol $10 \mathrm{mg} / \mathrm{kg}$ treated mice were also significantly $(\mathrm{p}<0.01)$ increased as compared to TAC control mice (Table 4).

4) Changes on the heart SOD activity

Significant $(p<0.01)$ decrease of heart endogenous antioxidative enzyme, the SOD activities were detected in TAC control mice as compared with sham control mice, but noticeable increases of SOD activities were observed in resveratrol $10 \mathrm{mg} / \mathrm{kg}$, LF 500, 250 and $125 \mathrm{mg} / \mathrm{kg}$ administrated mice as compared with TAC control mice, respectively (Table 4). 
Table 4. Heart Antioxidant Defense Systems Detected in Sham or TAC Operated Mice

\begin{tabular}{|c|c|c|c|c|}
\hline Groups & MDA (nM/g protein) & GSH (nM/g protein) & CAT (U/g protein) & SOD (U/g protein) \\
\hline \multicolumn{5}{|l|}{ Controls } \\
\hline Sham & $1.04 \pm 0.14$ & $5.13 \pm 0.45$ & $0.49 \pm 0.13$ & $7.97 \pm 1.84$ \\
\hline $\mathrm{TAC}$ & $3.53 \pm 0.55^{\mathrm{d}}$ & $1.42 \pm 0.44^{\mathrm{d}}$ & $0.17 \pm 0.04^{\mathrm{a}}$ & $2.52 \pm 0.51^{\mathrm{a}}$ \\
\hline Resveratrol $10 \mathrm{mg} / \mathrm{kg}$ & $2.08 \pm 0.16^{\mathrm{df}}$ & $2.95 \pm 0.15^{\mathrm{df}}$ & $0.32 \pm 0.03^{\mathrm{ab}}$ & $4.51 \pm 0.52^{\mathrm{ab}}$ \\
\hline \multicolumn{5}{|l|}{ LF treated } \\
\hline $500 \mathrm{mg} / \mathrm{kg}$ & $1.69 \pm 0.24^{\mathrm{df}}$ & $3.72 \pm 0.41^{\mathrm{ef}}$ & $0.43 \pm 0.06^{b}$ & $5.57 \pm 0.51^{\mathrm{ab}}$ \\
\hline $250 \mathrm{mg} / \mathrm{kg}$ & $2.09 \pm 0.16^{\mathrm{df}}$ & $2.91 \pm 0.26^{\mathrm{df}}$ & $0.32 \pm 0.04^{\mathrm{ab}}$ & $4.59 \pm 0.50^{\mathrm{ab}}$ \\
\hline $125 \mathrm{mg} / \mathrm{kg}$ & $2.32 \pm 0.33^{\mathrm{df}}$ & $2.62 \pm 0.54^{\mathrm{dg}}$ & $0.27 \pm 0.03^{\mathrm{ac}}$ & $3.46 \pm 0.56^{\mathrm{a}}$ \\
\hline
\end{tabular}

Values are expressed as Mean \pm S.D. of five mice, g.

TAC : transverse aortic constriction, LF : Lonicerae flos aqueous extracts, MDA : malondialdehyde, GSH : glutathione, CAT : catalase, SOD : superoxide dismutase

${ }^{a} p<0.01$ as compared to sham control by LSD test

${ }^{\mathrm{b}} p<0.01$ and ${ }^{\mathrm{p}}<0.05$ as compared to TAC control by LSD test

${ }^{\mathrm{d}} p<0.01$ and ${ }^{\mathrm{e}} \mathrm{p}<0.05$ as compared to sham control by MW test

${ }^{\mathrm{f}} p<0.01$ and ${ }^{\mathrm{g} p}<0.05$ as compared to TAC control by MW test

\section{Effects on the heart histopathology}

The total thicknesses of LV from endocardium to pericardium ( $\mu \mathrm{m} /$ heart), mean numbers of lytic necrotic cardiac muscle fibers (myofibers/1000 myofibers) and diameters of cardiac muscle fibers ( $\mu \mathrm{m} /$ fiber) were calculated to observe the heart damages as histomorphometrical analysis with the mean percentages of perivascular and interstitial collagen fiber occupied parts in LV (\%/mm ${ }^{2}$ of field), respectively.

1) Changes on the total thicknesses of left ventricle

In TAC control mice, significantly $(\mathrm{p}<0.01)$ increased total thicknesses of the LV from endocardium to pericardium were detected. However, 14 days sustained oral treatment of resveratrol $10 \mathrm{mg} / \mathrm{kg}$, LF 500, 250 and $125 \mathrm{mg} / \mathrm{kg}$ in TAC-operated mice significantly $(p<0.01)$ inhibited the TAC related ventricle hypertrophic changes. In addition, LF showed clear dose-dependent effects (Table 5, Fig 3).

2) Changes on the mean numbers of lytic necrotic cardiac muscle fibers in left ventricle

In TAC control mice, significantly $(p<0.01)$ increased mean numbers of lytic and necrotic muscle fibers in heart among 1000 myofibers were observed. However, 14 days sustained oral treatment of resveratrol 10 $\mathrm{mg} / \mathrm{kg}$, LF 500, 250 and $125 \mathrm{mg} / \mathrm{kg}$ in TAC-operated mice significantly $(p<0.01$ or $p<0.05)$ inhibited the $\mathrm{TAC}$ related increases of degenerative myofibers as compared with $\mathrm{TAC}$ control mice, respectively. In addition, LF showed clear dose-dependent effects (Table 5, Fig 3).

3) Changes on the diameters of cardiac muscle fibers in left ventricle

In TAC control mice, markedly ( $p<0.01)$ increased mean diameters of cardiac muscle fibers were demonstrated. However, 14 days sustained oral treatment of resveratrol $10 \mathrm{mg} / \mathrm{kg}$, LF 500, 250 and $125 \mathrm{mg} / \mathrm{kg}$ in TAC-operated mice significantly $(p<0.01)$ inhibited the TAC related increases of the diameters of muscle fibers in heart, respectively. In addition, LF detected clear dose-dependent effects 
(Table 5, Fig 3).

4) Changes on the mean percentages of perivascular collagen fiber occupied parts in left ventricle

The mean percentages of perivascular collagen fiber occupied parts in LV were significantly $(p<0.01)$ increased in TAC control mice. These TAC-related perivascular fibrosis were dose-dependently and markedly ( $p<0.01$ or $p<0.05$ ) restored by LF treatment. Furthermore, the mean percentages of perivascular collagen fiber occupied parts in LV were significantly $(p<0.01)$ decreased in resveratrol $10 \mathrm{mg} / \mathrm{kg}$ treated group (Table 5, Fig 3).
5) Changes on the mean percentages of interstitial collagen fiber occupied parts in left ventricle

The mean percentages of interstitial collagen fiber occupied parts in LV were significantly and markedly $(p<0.01)$ increased in TAC control mice. These TAC-related interstitial fibrosis were dose-dependently and markedly $(p<0.01$ or $p<0.05)$ restored by LF treatment. Furthermore, the mean percentages of interstitial collagen fiber occupied parts in LV were markedly $(p<0.01)$ decreased in resveratrol 10 $\mathrm{mg} / \mathrm{kg}$ treated group (Table 5, Fig 3).

Table 5. Heart Histomorphometrical Analysis Calculated in Sham or TAC Operated Mice

\begin{tabular}{|c|c|c|c|c|c|}
\hline \multirow[b]{2}{*}{ Groups } & \multirow{2}{*}{$\begin{array}{l}\text { Total LV thickness } \\
(\mu \mathrm{m} / \text { heart })\end{array}$} & \multirow{2}{*}{$\begin{array}{l}\text { Lytic and necrotic } \\
\text { myofiber numbers } \\
\text { (fibers/1000 fibers) }\end{array}$} & \multirow{2}{*}{$\begin{array}{c}\text { Myofiber mean } \\
\text { diameters } \\
(\mu \mathrm{m} / \text { fiber })\end{array}$} & \multicolumn{2}{|c|}{$\begin{array}{c}\text { Collagen occupied parts } \\
\left(\% / \mathrm{mm}^{2}\right)\end{array}$} \\
\hline & & & & $\begin{array}{l}\text { Perivascular } \\
\text { regions }\end{array}$ & $\begin{array}{l}\text { Interstitial } \\
\text { regions }\end{array}$ \\
\hline \multicolumn{6}{|l|}{ Controls } \\
\hline Sham & 1236. & 73 & & $2.89 \pm 0.70$ & $1.17 \pm 0.38$ \\
\hline $\mathrm{TAC}$ & $1943.34 \pm 141.10^{\mathrm{a}}$ & $643.00 \pm 167.17^{\mathrm{d}}$ & $29.53 \pm 3.27^{\mathrm{a}}$ & $33.64 \pm 6.97^{\mathrm{d}}$ & $33.90 \pm 5.21^{\mathrm{ad}}$ \\
\hline Resveratrol $10 \mathrm{mg} / \mathrm{kg}$ & $1471.37 \pm 90.54^{\mathrm{ac}}$ & $345.00 \pm 98.95^{\mathrm{dg}}$ & $21.41 \pm 2.73^{\mathrm{ac}}$ & $6.88 \pm 1.15^{\mathrm{df}}$ & $19.19 \pm 3.07^{\mathrm{ac}}$ \\
\hline \multicolumn{6}{|l|}{ LF treated } \\
\hline $500 \mathrm{mg} / \mathrm{kg}$ & $1356.34 \pm 77.82^{c}$ & $193.29 \pm 35.27^{\mathrm{df}}$ & $18.28 \pm 2.06^{\mathrm{bc}}$ & $4.40 \pm 0562^{\mathrm{ef}}$ & $8.03 \pm 2.83^{\mathrm{ac}}$ \\
\hline $250 \mathrm{mg} / \mathrm{kg}$ & $1487.75 \pm 131.51^{\mathrm{ac}}$ & $326.20 \pm 70.79 \mathrm{df}$ & $21.04 \pm 1.70^{\mathrm{ac}}$ & $6.64 \pm 0.91 \mathrm{df}$ & $17.85 \pm 3.57^{\mathrm{ac}}$ \\
\hline $125 \mathrm{mg} / \mathrm{kg}$ & $1576.39 \pm 135.34^{\mathrm{ac}}$ & $391.20 \pm 52.83^{\text {de }}$ & $24.79 \pm 2.00^{\mathrm{ac}}$ & $18.39 \pm 3.35^{\mathrm{df}}$ & $23.38 \pm 3.55^{\mathrm{ac}}$ \\
\hline
\end{tabular}

Values are expressed as Mean \pm S.D. of five mice, g.

LF : Lonicerae flos aqueous extracts, TAC : transverse aortic constriction, LV : left ventricle

${ }^{a} p<0.01$ and ${ }^{b} p<0.05$ as compared to sham control by LSD test

${ }^{c} p<0.01$ as compared to TAC control by LSD test

${ }^{\mathrm{d}} p<0.01$ and ${ }^{\mathrm{e}} \mathrm{p}<0.05$ as compared to sham control by MW test

${ }^{\mathrm{f}} p<0.01$ and ${ }^{\mathrm{p}} \mathrm{p}<0.05$ as compared to TAC control by MW test 




Fig. 3. The typical general histological images of heart and collagen stained histological images of left ventricle, taken from sham or TAC operated mice.

A : sham control, B : TAC control, C : resveratrol $10 \mathrm{mg} / \mathrm{kg}$, D : LF $500 \mathrm{mg} / \mathrm{kg}, \mathrm{E}: \mathrm{LF} 250 \mathrm{mg} / \mathrm{kg}$, F : LF $125 \mathrm{mg} / \mathrm{kg}$ LF : Lonicerae flos aqueous extracts, TAC : transverse aortic constriction, LV : left ventricle, RV : right ventricle All Hematoxylin-Eosin stain

Scale bars : $100 \mu \mathrm{m}$

\section{Discussion}

Resveratrol, a polyphenol with antioxidant, anti-apoptotic, anti-inflammatory and metabolic properties was recently identified as an activator of energy metabolism ${ }^{10}$. In the heart, resveratrol decreases pressure overload-induced hypertrophy and contractile dysfunction ${ }^{11}$. Because of its positive effects on vascular function and energy metabolism ${ }^{12}$, we used it as a reference drug.

In the present study, the cardioprotective effects of LF, a dried flower part of Lonicerae japonica Thunb. which has been widely used as anti-inflammatory and antioxidative agent in Korean medicine ${ }^{7 ., 13}$, were observed on the PO HF induced by TAC in C57BL/6 mice $^{14-16}$ through possible antioxidant effects. In this experiment, resveratrol $10 \mathrm{mg} / \mathrm{kg}$, LF 500, 250 and $125 \mathrm{mg} / \mathrm{kg}$ were administered in mouth, once a day during 14 days, from 14 days after TAC surgery. And the changes in the mortality, body weights, heart weights, heart histopathology, and antioxidant defense system of the heart were analyzed $^{14}$. The heart MDA contents were observed for lipid peroxidation, GSH contents, CAT and SOD activities were observed for antioxidant effects ${ }^{17.18}$, and also the overall thicknesses of LV from endocardium to pericardium, mean numbers of diameters of cardiac muscle fibers and lytic necrotic cardiac 
muscle fibers were calculated for histomorphometrical analysis with the mean percentages of interstitial and perivascular collagen fiber occupied parts in $\mathrm{LV}$, respectively ${ }^{14.16}$.

The dosages of LF were selected according to the results of previous animal studies ${ }^{7.8}$. In this experiment, the results were compared to resveratrol, in which influential cardioprotective effects on TAC mice model were confirmed at a dose level of $10 \mathrm{mg} / \mathrm{kg}$ through antioxidant effects, as reference in this experiment ${ }^{14}$.

Corresponding to the previous studies ${ }^{14-16}$ TAC surgery induced marked increases of mortality, heart weights, and hypertrophic, focal and lytic fibrotic histological changes in the LVs were observed with collapse of antioxidant defense systems - the increases of heart MDA contents, decreases of GSH contents, CAT and SOD activities in TAC control mice as compared to sham control mice, respectively. However, these HF signs caused by TAC surgery through PO and destroyed heart antioxidant defense systems were noticeably and dose-dependently hindered by 14 days constant oral treatment of LF 500, 250 and $125 \mathrm{mg} / \mathrm{kg}$, respectively. Accordingly it is considered as tangible evidences that LF favorably mitigates PO-induced HF by TAC, through enhancement of heart antioxidant defense system. The overall effects of LF $250 \mathrm{mg} / \mathrm{kg}$ were comparable to those of resveratrol $10 \mathrm{mg} / \mathrm{kg}$, in this study.

No significant changes on the body weight were detected in TAC control mice as compared with sham control mice; as a result, TAC surgery did not influenced on the body weight increase for 14 days of maintaining oral administration periods in the current result. In addition, LF 500, 250, and $125 \mathrm{mg} / \mathrm{kg}$ and resveratrol $10 \mathrm{mg} / \mathrm{kg}$ also did not influenced on the body weight and increases as compared with those of sham and TAC control mice, throughout all experimental periods. All C57BL/6 mice used in the present experiment containing TAC control mice and resveratrol $10 \mathrm{mg} / \mathrm{kg}$ treated mice, showed normal body weight and increases throughout 14 days of experimental periods, varied in age-matched normal reference C57BL/6 mice ${ }^{19.20}$. According to the previous TAC experiments ${ }^{15-17}$, survivability of animals from TAC surgery was reached upto $60-80 \%$, and also detected as $62.50 \%$ in TAC control mice in this study. However, noticeable increases of survivabilities were demonstrated by oral treatment of LF 125, 250 and $500 \mathrm{mg} / \mathrm{kg}$ as $75.0,87.5$ and 100.0\%, dose-dependently and by resveratrol $10 \mathrm{mg} / \mathrm{kg}$ as $87.5 \%$ in this result. Especially, LF $250 \mathrm{mg} / \mathrm{kg}$ showed resembling increases of the survival percentages as analogous to those of resveratrol $10 \mathrm{mg} / \mathrm{kg}$, and unscheduled mortalities were not demonstrated in LF $500 \mathrm{mg} / \mathrm{kg}$ treated mice all through the whole 14 days of experimental periods, as analogous to those of sham control, in this experiment. These finding on the survival percentages considered as direct evidences that LF can suppress PO-induced $\mathrm{HF}$ and mortalities from it, analogous to those of resveratrol $10 \mathrm{mg} / \mathrm{kg}$ in a dose level of $250 \mathrm{mg} / \mathrm{kg}$.

$\mathrm{HF}$ is preceded by left ventricular hypertrophy (LVH) in response to PO. LVH compensates for the PO, however, defective remodeling impairs left ventricular function ${ }^{14}$. Although cardiac hypertrophy is an adaption that is useful to the damaged heart in the initial stages wherein cardiomyocytes expand in size to achieve competent function in the existence of chronic pathological stress ${ }^{21}$, this compensatory phase is impermanent because in the face of continued damage the heart enters into a decompensatory stage, eventually ${ }^{22}$. This change from recompensable to decompensatory stage is characterized by noticeable 
increases in cardiac fibrosis, apoptosis, and hypoxia that lead to irreversible changes and $\mathrm{HF}^{23-25}$. In the present study, noticeable increases of heart weights were demonstrated in TAC control mice with lytic, focal fibrotic and hypertrophic histological changes in the LVs, as summarized by other investigators ${ }^{14-16}$ implying change from compensatory to decompensatory status in TAC-induced PO HF. However, these increases in weight of heart and lytic, hypertrophic and focal fibrotic histological changes in the LVs were markedly and dose-dependently reserved by 14 days continuous oral treatment of LF 500, 250 and $125 \mathrm{mg} / \mathrm{kg}$, respectively. Especially, LF $250 \mathrm{mg} / \mathrm{kg}$ showed similar effects on the heart weights and histopathological changes as comparable with those of resveratrol $10 \mathrm{mg} / \mathrm{kg}$. Theses results are considered as direct proof that LF considerably relieves PO-induced HF by TAC as comparable with those of resveratrol $10 \mathrm{mg} / \mathrm{kg}$ in a dose level of $250 \mathrm{mg} / \mathrm{kg}$, in this experiment.

GSH is typical endogenous antioxidants and inhibit tissue damage by keeping the ROS at inadequate levels and at definite cellular concentrations and admitted as protective antioxidant factors in tissues $^{28}$. SOD is one of the antioxidant enzymes that contribute to enzymatic defense mechanisms also in heart ${ }^{17.26 .27}$. CAT is an enzyme catalyzes the conversion of $\mathrm{H}_{2} \mathrm{O}_{2}$ to $\mathrm{H}_{2} \mathrm{O}^{29}$ So the inhibition of increased lipid peroxidation and ROS, with increases in GSH contents, CAT and SOD activities are in the damaged cerebral tissue is secondarily important in terms of helping protection for heart damages in $\mathrm{HF}^{11.25}$. In this study, TAC surgery significantly increased lipid peroxidation, as increase of MDA contents, decreases of reactive oxygen species scavenging enzymes' activity like CAT and SOD, and also GSH levels in heart tissue. However, LF treatments were found to significantly and dose-dependently prohibit heart lipid peroxidation, and elevate the CAT and SOD activity and GSH levels in comparison with TAC control mice, as similar to those of resveratrol $10 \mathrm{mg} / \mathrm{kg}$ in LF $250 \mathrm{mg} / \mathrm{kg}$ of the current result. These results suggest that the cardioprotective effects of LF, in part, mediated by enhancement of antioxidant defense systems.

LF, as a traditional Korean medicine, was used widely in diseases such as common cold, carbuncles, febrile disease, dysentery, and virulent swellings ${ }^{7}$ through latent-heat-clearing, detoxicant, antipyretic, and anti-inflammatory actions ${ }^{7,813}$. The accumulated evidence has demonstrated that LF has dozens of chemical components such as flavones derivates (luteolin, lonicerin, ochnaflavone, loniceroside A, B and $\mathrm{C}$ ), secoiridoid glycosides (loniceracetalides A and B, loganin, secologanin, dimethyl acetal, sweroside, kingiside, morroniside, 8-epiloganin, vogelosdie), polyphenols (methyl caffeate, 3,4-di-0-caffeoylquine and methyl 3,4-di-0-caffeoylquine) and others (chlorogenic acid) ${ }^{22}$. Among them, it is also reported that chlorogenic acid are well distributed into the heart after oral administration in rats ${ }^{30}$. For more detail mechanism studies, screening of the biological active compounds in LF is necessary.

\section{v. Conclusion}

The results obtained in the present study suggest that oral administration of LF favorably alleviates PO-induced HF by TAC, through enhancement of heart antioxidant defense system, at the very least in a condition of this experiment. The overall effects of $\mathrm{LF} 250 \mathrm{mg} / \mathrm{kg}$ were similar to those of resveratrol $10 \mathrm{mg} / \mathrm{kg}$. However, LF is usually prescribed in mixed form with various herbal medicine in clinical field, 
and optimal stage of use in heart damage is yet unknown. Therefore, more diverse but detail mechanism studies of LF should be conducted in future with functional restoration in heart damages.

\section{References}

1. Braunwald E. The war against heart failure: the Lancet lecture. Lancet 2015:385(9970):812-24.

2. Roger VL, Go AS, Lloyd-Jones DM, Benjamin EJ, Berry JD, Borden WB, et al. on behalf of the American Heart Association Statistics Committee and Stroke Statistics Subcommittee. Heart disease and stroke statistics 2012 update: a report from the American Heart Association. Circulation 2012; 125(1): :2-e220.

3. Ponikowski P, Voors AA, Anker SD, Bueno H, Cleland JG, Coats AJ, et al. 2016 ESC Guidelines for the diagnosis and treatment of acute and chronic heart failure: The Task Force for the diagnosis and treatment of acute and chronic heart failure of the European Society of Cardiology (ESC) Developed with the special contribution of the Heart Failure Association (HFA) of the ESC. Eur Heart J 2016;37(27):2129-200.

4. Munzel T, Gori T, Keaney JF, Maack C, Daiber A. Pathophysiological role of oxidative stress in systolic and diastolic heart failure and its therapeutic implications. European Heart Journal 2015;36(38) :2555-64. doi:10.1093 /eurheartj/ehv305.

5. Hunt SA, Abraham WT, Chin MH, Feldman AM, Francis GS, Ganlats TG, et al. 2009 Focused update incorporated in to the ACC/AHA 2005 Guidelines for the Diagnosis and Management of Heart Failure in Adults A report of the American College of Cardiology Foundation/American Heart Association Task Force on Practice Guidelines
Developed in Collaboration with the international Society for Heart and Lung Transplantation. $J$ Am Coll Cardiol 2009:53(15):e1-e90.

6. Ezekowitz JA, Kaul P, Bakal JA, Quan H, McAlister FA. Trends in heart failure care: has the incident diagnosis of heart failure shifted from the hospital to the emergency department and outpatient clinics? Eur J Heart Fail 2011;13(2) :142-7. doi:10.1093/eurjhf/hfa185.

7. Ku SK, Seo BI, Park JH, Park GY, Seo YB, Kim JS, et al. Effect of Lonicerae Flos extracts on reflux esophagitis with antioxidant activity. World J Gastroenterol 2009;15(38):4799-805.

8. Ku SK, Lee YJ. Effects of Lonicerae Flos on the 6-n-propyl-2-thiouracil (PTU)-induced rat hyperthyroidism. Korean $J$ Orient Physiol Pathol 2010;24(4):630-7.

9. Tian J, Che H, Ha D, Wei Y, Zheng S. Characterization and anti-allergic effect of a polysaccharide from the flower buds of Lonicera japonica. Carbohydrate Polymers 2012:90(4):1642-7.

10. Elliott PJ, Jirousek M. Sirtuins: novel targets for metabolic disease. Curr Opin Investig Drugs 2008:9(4):371-8.

11. Dolinsky VW, Chan AY, Robillard Frayne I, Light PE, Des Rosiers C, Dyck JR. Resveratrol prevents the prohypertrophic effects of oxidative stress on LKB1. Circulation 2009;119(12):1643-52.

12. Rimbaud S, Ruiz M, Piquereau J, Mateo P, Fortin D, Veksler V, et al. Resveratrol Improves Survival, Hemodynamics and Energetics in a Rat Model of Hypertension Leading to Heart Failure. PloS one 2011;6(10):e26391.

13. Lan W, Zhaojun Z, Zesheng Z. Characterization of antioxidant activity of extracts from Flos Lonicerae. Drug Dev Ind Pharm 2007;33(8) :841-7. 14. Gupta PK, DiPette DJ, Supowit SC. Protective 
effect of resveratrol against pressure overloadinduced heart failure. Food Sci Nutr 2014;2(3) :218-29.

15. Qi J, Liu Q, Gong K, Yu J, Wang L, Guo L, et al. Apocynum tablet protects against cardiac hypertrophy via inhibiting AKT and ERK1/2 phosphorylation after pressure overload. Evid Based Complement Alternat Med 2014;2014:769515.

16. Songstad NT, Johansen D, How OJ, Kaaresen PI, Ytrehus K, Acharya G. Effect of transverse aortic constriction on cardiac structure, function and gene expression in pregnant rats. PLoS One 2014:9(2):e89559.

17. van Empel VP, Bertrand AT, van Oort RJ, van der Nagel R, Engelen M, van Rijen HV, et al. EUK-8, a superoxide dismutase and catalase mimetic, reduces cardiac oxidative stress and ameliorates pressure overload-induced heart failure in the harlequin mouse mutant. $J \mathrm{Am}$ Coll Cardiol 2006;48(4):824-32.

18. Bento DB, de Souza B, Steckert AV, Dias RO, Leffa DD, Moreno SE, et al. Oxidative stress in mice treated with antileishmanial meglumine antimoniate. Res Vet Sci 2013;95(3) :1134-41.

19. Fox JG, Cohen BJ, Loew FM. Laboratory animal medicine. Orlando: Academic Press Inc; 1984.

20. Tajima Y (Ed). Biological reference data book on experimental animals. Tokyo: Soft Science Inc; 1989.

21. Frey N, Olson EN. Cardiac hypertrophy: the good, the bad, and the ugly. Annu Rev Physiol 2003;65:45-79.

22. Gersh BJ, Maron BJ, Bonow RO, Dearani JA, Fifer MA, Link MS, et al. American College of Cardiology Foundation/American Heart Association
Task Force on Practice Guidelines. 2011 ACCF/AHA Guideline for the Diagnosis and Treatment of Hypertrophic Cardiomyopathy: a report of the American College of Cardiology Foundation/ American Heart Association Task Force on Practice Guidelines. Developed in collaboration with the American Association for Thoracic Surgery, American Society of Echocardiography, American Society of Nuclear Cardiology, Heart Failure Society of America, Heart Rhythm Society, Society for Cardiovascular Angiography and Interventions, and Society of Thoracic Surgeons. $J$ Am Coll Cardiol 2011;58(25):e212-60.

23. Juric D, Wojciechowski P, Das DK, Netticadan T. Prevention of concentric hypertrophy and diastolic impairment in aortic-banded rats treated with resveratrol. Am $J$ Physiol Heart Circ Physiol 2007;292(5) :H2138-43.

24. Wojciechowski P, Juric D, Louis XL, Thandapilly SJ, Yu L, Taylor C, et al. Resveratrol arrests and regresses the development of pressure overloadbut not volume overload-induced cardiac hypertrophy in rats. J Nutr 2010;140(5):962-8.

25. Yu S, Li G. MicroRNA expression and function in cardiac ischemic injury. $J$ Cardiovasc Transl Res 2010:3(3):241-5.

26. Dai DF, Hsieh EJ, Liu Y, Chen T, Beyer RP, Chin MT, et al. Mitochondrial proteome remodelling in pressure overload-induced heart failure: the role of mitochondrial oxidative stress. Cardiovasc Res 2012:93(1):79-88.

27. Koga K, Kenessey A, Ojamaa K. Macrophage migration inhibitory factor antagonizes pressure overload-induced cardiac hypertrophy. Am $J$ Physiol Heart Circ Physiol 2013:304(2):H282-93.

28. Odabasoglu F, Cakir A, Suleyman H, Aslan A, Bayir Y, Halici M, et al. Gastroprotective and 
Protective Effect of Lonicerae Flos Aqueous Extracts on a Pressure Overload-induced Heart Failure Model

antioxidant effects of usnic acid on indomethacininduced gastric ulcer in rats. $J$ Ethnopharmacol 2006;103(1):59-65.

29. Cheeseman KH, Slater TF. An introduction to free radical biochemistry. Br Med Bull 1993; $49(3): 481-93$.
30. Zhou Y, Zhou T, Pei Q, Liu S, Yuan H. Pharmacokinetics and tissue distribution study of chlorogenic Acid from lonicerae japonicae flos following oral administrations in rats. Evid Based Complement Alternat Med 2014;2014 :979414. 